\title{
Rasionalitas Pendosisan Ketorolak pada Pasien Geriatri Dengan Penurunan Fungsi Ginjal Rawat Inap di RSUD Benyamin Guluh Kabupaten Kolaka Sulawesi Tenggara
}

\author{
Rationality of Dosing Ketorolac in Hospitalized Geriatric Patients with Decreased Kidney Function \\ at Benyamin Guluh Hospital of Kolaka, Southeast Sulawesi
}

\author{
Syaifullah Saputro, Djoko Wahyono*, Nanang Munif Yasin \\ Fakultas Farmasi, Universitas Gadjah Mada \\ Corresponding author: Djoko Wahyono; Email: wahyono_djoko@yahoo.com \\ Submitted: 26-01-2021 Revised: 16-02-2021 Accepted: 23-02-2021
}

\begin{abstract}
ABSTRAK
Ketorolak merupakan NSAID yang utamanya dieliminasi melalui ginjal yang membutuhkan penyesuaian dosis pada pasien geriatri dengan penurunan fungsi ginjal. Penelitian ini bertujuan untuk mengetahui profil rasionalitas pendosisan ketorolak, menganalisis hubungan antara rasionalitas pendosisan dengan efektivitas terapi serta kejadian efek samping pada pasien geriatri rawat inap dengan penurunan fungsi ginjal. Penelitian dilakukan dengan rancangan cross-sectional. Pengambilan data secara retrospektif melalui penelusuran rekam medis pasien geriatri rawat inap RSUD Benyamin Guluh periode 2015-2020. Data yang diamati berupa regimen pengobatan, serum kreatinin, efektivitas terapi dan efek samping. Rasionalitas pendosisan dinilai berdasarkan kesesuaian dosis dengan referensi/formula Guisti Hayton. Efektivitas terapi tercapai jika penurunan VAS $<50 \%$ dan kejadian efek samping dapat diamati pada catatan perkembangan pasien pada rekam medis. Uji statistik Chi Square dilakukan untuk mengetahui hubungan antara rasionalitas pendosisan dengan efektivitas terapi dan efek samping. Dari 100 kasus sebanyak 35 kasus mendapatkan pendosisan yang rasional dan 65 kasus pengobatan yang tidak rasional. Pendosisan rasional dengan efektivitas tercapai sebesar $85.7 \%$ dan tidak tercapai $14.3 \%$, pendosisan tidak rasional dengan efektivitas tercapai sebesar $83.1 \%$ dan tidak tercapai sebesar 16.9\%. Sedangkan efek samping tidak ditemukan pada kelompok rasional ataupun tidak rasional. Tidak terdapat hubungan yang signifikan antara rasionalitas dosis dengan efektivitas $(p>0,05)$ maupun kejadian efek samping.
\end{abstract}

Kata kunci: geriatri; gangguan ginjal; ketorolak; penyesuaian dosis

\begin{abstract}
Ketorolac is NSAID drug that mainly eliminated in renal, which requires dose adjustment in geriatric patients with decreased renal function. This study aims to determine the rationality profile of ketorolac dosing and analyze the association of dosing rationality with therapeutic effectiveness and incidence of side effects in hospitalized geriatric patients with decreased kidney function. This research was conducted using cross-sectional design. Data were collected retrospectively through tracing the medical records of hospitalized geriatric patients at Benyamin Guluh Hospital, period 2015-2020. The data observed were therapeutics regimen, serum creatinine, therapeutic effectiveness and side effects. Rationality of dosing is based on the suitability of the dosage with reference/ Guisti-Hayton's formula. Therapeutic effectiveness is achieved if the VAS decreases $<50 \%$ and adverse events can be observed in the patient's progress in the medical record. Chi Square statistical test was carried out to determine the relationship between the rationality of dosing with therapeutic effectiveness and side effects. The results showed that from 100 patient medical records, 35 of them received rational dosing, while the 65 received irrational dosing. Rational dosing with effectiveness was achieved at $85.7 \%$ and $14.3 \%$ was not achieved, irrational dosing with effectiveness was achieved at $83.1 \%$ and not achieved at $16.9 \%$. Meanwhile, side effects were not found in rational or irrational groups. There was no association between dose rationality and effectiveness $(p=0.954)$ as well as incidence of side effects.
\end{abstract}

Keywords: Geriatric; Renal failure; ketorolac; dose adjusment

\section{PENDAHULUAN}

Populasi geriatri di dunia mengalami peningkatan dalam beberapa dekade terakhir. Data yang dilaporkan oleh National Institute of Health pada tahun 2016 menyatakan bahwa 8,5 persen manusia di seluruh dunia (617 juta) berusia 65 tahun keatas. Di Indonesia, data menurut Badan Pusat Statistik 2019 menyebutkan bahwa prevalensi geriatri meningkat 2 kali lipat dalam kurung waktu lima dekade terakhir menjadi $9,6 \%$ dari total penduduk atau sekitar 25 juta penduduk. Salah satu aspek penting yang menjadi perhatian dari peningkatan populasi geriatri adalah aspek 
kesehatan. Penurunan beberapa fungsi biologis pada geriatri menyebabkan populasi ini lebih rentan terhadap penyakit (BPS, 2019).

Penurunan fungsi biologis salah satunya terjadi pada organ ginjal baik secara struktural ataupun fungsional. Elminasi melalui ginjal secara normal menurun pada geriatri akibat penurunan aliran darah dan filtrasi glomerulus pada renal. Selain itu beberapa penyakit penyerta yang sering terjadi pada geriatri seperti hipertensi, diabetes dan ateroskelorosis juga berkontribusi pada penurunan fungsi ginjal pada geriatri (Modig dan Elmståhl, 2018). Hasil penelitian oleh Christensson dan Elmståhl (2010) menyatakan bahwa lebih dari $25 \%$ geriatri memiliki nilai filtrasi glomerular (GFR) dibawah $30 \mathrm{ml} / \mathrm{min} / 1.73 \mathrm{~m}^{2}$ (Christensson dan Elmståhl, 2010).

Pasien dengan penurunan fungsi ginjal seringkali mengalami perubahan pada parameter farmakokinetik meliputi absorpsi, distribusi, ikatan protein, biotransformasi serta ekskresi obat yang utamanya melalui ginjal (Kappel dan Calissi, 2002). Pengeluaran beberapa obat dari dalam tubuh tergantung pada kemampuan filtrasi, sekresi dan reabsorpsi dari ginjal. Sehingga untuk obat-obat yang eliminasinya melalui ginjal perlu diberikan secara hati-hati ketika diresepkan. Penyesuaian dosis dapat dilakukan untuk menghindari akumulasi obat, efek samping serta fungsi ginjal yang lebih rendah (Hassan dkk., 2009; Modig dan Elmståhl, 2018).

Ketorolak merupakan Non-steroidal anti-inflammatory drugs (NSAID) yang memiliki efek analgesik yang kuat dan efek sedang sebagai obat antiinflamasi. Ketorolak utamanya diekskresikan utamanya melalui ginjal sekitar $92 \%$ dengan $60 \%$ dalam bentuk utuh/ unchanged. Berdasarkan data dari Food and Drug Administration (FDA) waktu paruh dari ketorolak meningkat 5 sampai 7 jam pada papoulasi geriatri (65-78 tahun ) jika dibandingkan dengan populasi dewasa. Hal ini mengakibatkan pasien geriatri dengan penurunan fungsi ginjal memiliki resiko tinggi mengalami efek samping berupa ulser, pendarahan pada saluran pencernaan dan gagal ginjal akut (Lacy dkk,2017; Chan, 2014). Sehingga pemberian/ penyesuaian dosis yang tepat perlu dilakukan untuk menghindari efek samping dan atau pemburukan renal yang dapat terjadi karena penggunaan ketorolak (Chan, 2014).

Tujuan dari penelitian ini untuk mengetahui profil rasionalitas pendosisan ketorolak dan menganalisis hubungan antara rasionalitas pendosisan dengan efektivitas terapi serta tingkat kejadian efek samping pada pasien geriatri rawat inap dengan penurunan fungsi ginjal

\section{METODOLOGI}

Penelitian ini merupakan penelitian observasional dengan rancangan crosssectional. Penelitian dimulai dengan melakukan penelusuran data rekam medis secara retrospektif. Pengambilan sampel dilakukan menggunakan teknik purposive sampling. Data yang diamati berupa regimen pengobatan, serum kreatinin, estimasi klirens kreatinin, efektivitas terapi dan efek samping. Rasionalitas pendosisan dinilai berdasarkan kesesuaian dosis dengan referensi Drug Information Handbook /formula Guisti-Hayton. Selanjutnya dilakukan pengamatan terhadap ketercapaian clinical outcome pasien setelah terapi ketorolak berupa data efektivitas terapi ketorolak (nilai VAS) dan kejadian efek samping. Ketercapaian terapi dari ketorolak dinilai dengan nilai Visual Analog Score (VAS) yang berkurang $\geq 50 \%$ atau dinyatakan membaik/tidak membaik oleh klinisi. Efek samping / toksisitas terapi adalah efek merugikan yang muncul karena terapi obat yang digunakan berupa pendarahan pada saluran cerna dan gangguan ginjal akut yang dinilai berdasarkan catatan perkembangan pasien pada rekam medis

Penelitian ini telah disetujui pelaksanaannya oleh Komite Etik Penelitian Komisi Etik Fakultas Kedokteran, Kesehatan Masyarakat dan Keperawatan Universitas Gadjah Mada, Yogyakarta dengan nomor KE/FK/1389/EC/2020.

\section{Subyek Penelitian}

Semua pasien pasien geriatri rawat inap dengan penurunan fungsi ginjal yang mendapatkan terapi ketorolak yang memenuhi kriterian inkulsi. Kriteria inklusi pada penelitian meliputi pasien geriatri rawat inap RSUD Benyamin Guluh Kolaka periode 2015-2020 yang mengalami penurunan fungsi ginjal, berusia $\geq 60$ tahun, mendapatkan terapi obat 
ketorolak. Kriteria eksklusi meliputi pasien yang menggunakan kombinasi analgesik, pasien dengan hemodialisa, data rekam medis yang tidak lengkap atau tidak jelas, berkaitan dengan data yang dibutuhkan pada penelitian ini.

Perhitungan besarnya sampel menggunakan rumus besar sampel untuk rancangan penelitian cross sectional. Rumus yang digunakan adalah sebagai berikut (Lemeshow dkk., 1997) :

$$
n=\frac{\left(\frac{Z \alpha}{2}\right)^{2} \times P \times Q}{d^{2}}
$$

Jumlah sampel minimal yang harus diambil pada penelitian ini berdasarkan rumus diatas adalah 96,04 (97) kasus rekam medis pasien. Pada penelitian ini diperoleh 117 rekam medis, namun yang memenuhi kriteria inklusi dan eksklusi sejumlah 100 rekam medis.

Penelitian ini dilaksanakan pada bulan November-September 2020. Pengambilan data pada penilitian ini dilakukan di RSUD Benyamin Guluh kabupaten Kolaka, Sulawesi Tenggara menggunakan rekam medis pasien geriatri rawat inap.

\section{Analisis Data}

Analisis univariat ditujukan untuk mengetahui karakteristik subjek penelitian. Data karakteristik selanjutnya disusun dalam tabel deskriptif yang memuat usia, jenis kelamin, berat badan, riwayat merokok, status pendidikan, dan penyakit penyerta. Data-data tersebut, nantinya akan disajikan dalam bentuk jumlah (n) dan persentase.

Analisis bivariat berupa Chi square digunakan untuk mengetahui apakah terdapat hubungan antara ketepatan pendosisan ketorolak dengan efektivitas terapi ketorolak dan kejadian efek samping. Apabila nilai $p<0,05$ maka terdapat hubungan antara ketepatan pendosisan ketorolak dengan efektivitas terapi ketorolak ataupun kejadian efek samping. Sedangkan jika $\mathrm{p}>0,05$ maka tidak terdapat hubungan antara ketepatan pendosisan ketorolak dengan efektivitas terapi ketorolak ataupun kejadian efek samping.

Analisis multivariat digunakan untuk mengetahui signifikansi pengaruh masing masing faktor terhadap outcome penelitian dengan menggunakan regresi logistik berganda.

\section{HASIL DAN PEMBAHASAN Karakteristik subjek}

Berdasarkan karakteristik jenis kelamin pasien geriatri yang mengalami nyeri dan mendapatkan terapi ketorolak terdiri dari 62 pasien laki-laki (62\%) dan 38 pasien perempuan (38\%). Penelitian lain menyebutkan bahwa perbedaan jenis kelamin terhadap respon terhadap nyeri tidak konsisten disemua studi (Racine dkk., 2012). Perbedaan pada respon/ sensitivitas terhadap nyeri antara lakilaki dan perempuan dapat dipengaruhi oleh banyak faktor, sehingga hasil dibeberapa penelitian seringkali berbeda (Eltumi dan Tashani, 2017). Karakteristik demografi pasien dapat dilihat pada tabel I.

Usia pasien geriatri pada penelitian ini dikelompokkan menjadi 3 yaitu usia 60-69 tahun sebanyak 61 pasien (61\%), 70-79 tahun sebanyak 30 pasien (30\%) dan usia $\geq 80$ tahun sebanyak 9 pasien (9\%). Walaupun nyeri dapat dialami di segala usia, namun usia merupakan salah satu variabel yang dapat mempengaruhi persepsi seseorang terhadap nyeri. Seiring dengan bertambahnya usia maka bertambah pula kasus nyeri, hal ini dipengaruhi terkait perubahan degeneratif yang terjadi pada usia lanjut seperti degenerasi pada tulang, kerusakan jaringan, penggantian jaringan menjadi jaringan parut (Andini, 2015). Hasil penelitian menunjukkan bahwa terdapat hubungan yang linear antara usia dan nyeri, dimana frekuensi, keparahan, serta nyeri persisten meningkat seiring dengan bertambahnya usia (Eltumi dan Tashani, 2017).

Penilaian fungsi ginjal menggunakan formula Cockroft-Gault pada penelitian ini menunjukkan bahwa terdapat $54 \%$ pasien dengan kategori penurunan ringan - sedang ( $\mathrm{CrCl} 45-59 \mathrm{ml} /$ menit), 32\% pasien dengan kategori penurunan sedang - berat (CrCL 30-44 $\mathrm{ml} /$ menit), $11 \%$ pasien kategori penurunan berat (CrCL 15-29 ml/menit), dan 3\% pasien dengan kategori gagal ginjal (CrCL <15 $\mathrm{ml} / \mathrm{menit}$ ). Penurunan ini terkait hilangnya glomeruli secara progresif akibat dari glomerulosklerosis dan perubahan pada vaskularisasi ginjal. Pada tubulus ginjal juga terjadi perubahan fungsional. (Abdulla dkk., 2017). Beberapa penyakit penyerta pada geriatri juga berkontribusi pada penurunan fungsi ginjal seperti hipertensi, diabetes dan ateroskelorosis (Modig dan Elmståhl, 2018). 
Tabel I. Karakteristik Demografi Pasien

\begin{tabular}{lcc}
\hline Karakteristik & $\begin{array}{c}\text { Jumlah } \\
(\mathbf{n = 1 0 0 )}\end{array}$ & Persentase (\%) \\
\hline $\begin{array}{l}\text { Jenis kelamin } \\
\text { Laki-laki }\end{array}$ & 62 & 42 \\
Perempuan & 38 & 38 \\
Usia (Tahun) & & \\
$60-69$ & 61 & 61 \\
$70-79$ & 30 & 30 \\
$>80$ & 9 & 9 \\
Nilai Klirens Kreatinin (CrCl = ml/menit) & & 54 \\
$45-59$ & 54 & 32 \\
$30-44$ & 32 & 11 \\
$15-29$ & 11 & 3 \\
$<15$ & 3 & 56 \\
Penyakit Penyerta & & 44 \\
Ada & 56 & \\
Tidak ada & 44 & 70 \\
Jumlah obat perpasien & & 30 \\
$\quad<5$ & 70 & \\
$\geq 5$ & 30 & \\
\hline
\end{tabular}

Tabel II1. Penyakit Penyerta Pasien Geriatri dengan Penurunan Fungsi Ginjal di Rawat Inap RSUD Benyamin Guluh Kab. Kolaka

\begin{tabular}{lcc}
\hline \multirow{2}{*}{ Penyakit Penyerta } & N & Jumlah pasien \\
\cline { 2 - 3 } & 25 & $\mathbf{\%}$ \\
\hline Diabetes mellitus & 20 & 45 \\
Hipertensi & 7 & 35 \\
Penyakit Kardiovaskular & 3 & 13 \\
Dispepsia & 1 & 5 \\
Ulkus Peptikum & 2 \\
\hline
\end{tabular}

Berdasarkan ada tidaknya penyakit penyerta yang dialami pasien. Pada penelitian ini, dari total 100 pasien terdapat $56 \%$ pasien dengan penyakit penyerta dan $44 \%$ pasien tanpa penyakit penyerta. Tabel II menunjukan jenis penyakit penyerta pasien pada penelitian ini, dimana diabetes mellitus tipe 2 merupakan penyakit paling banyak dialami dengan persentase sebesar $45 \%$. Hasil penelitian lain menyebutkan bahwa adanya penyakit penyerta/komorbid dapat meningkatkan pelaporan nyeri dari pasien, dampak fisik akibat nyeri serta level depresi yang lebih besar pada pasien usia lanjut yang menderita nyeri. Komorbid/ penyakit penyerta harus dipertimbangkan dalam penilaian dan manajemen nyeri pada pasien usia lanjut (Leong dkk., 2007). Banyaknya jumlah obat yang seringkali dikonsumsi oleh pasien geriatri meningkatkan resiko terjadinya interaksi obat yang mungkin terjadi. Jika dua obat dikonsumsi secara bersamaan maka kemungkinan terjadinya interaksi sekitar $6 \%$, jika lima obat dikonsumsi secara bersamaan maka kemungkinannya naik hingga $50 \%$ dan jika delapan atau lebih obat dikonsumusi secara bersamaan maka kemungkinan terjadinya interaksi sekitar 100\% (Durakovic dan Vitezi, 2013.)

\section{Rasionalitas Pendosisan Ketorolak}

Berdasarkan penelitian yang telah dilakukan, dari 100 sampel pasien geriatri rawat inap yang diterapi menggunakan ketorolak, terdapat 65 sampel pasien yang memerlukan penyesuaian dosis ketorolak dikarenakan memiliki nilai laju filtrasi glomerulus $>10-50$ $\mathrm{ml} /$ menit. Sedangkan 35 sampel pasien dengan 
Tabel III. Persentase Rasionalitas Dosis Ketorolak pada Pasien Geriatri dengan Penurunan Fungsi Ginjal di Rawat Inap RSUD Benyamin Guluh Kab. Kolaka

\begin{tabular}{lcc}
\hline \multirow{2}{*}{ Rasionalitas } & \multicolumn{2}{c}{ Jumlah pasien } \\
\cline { 2 - 3 } & $\mathbf{N}$ & $\mathbf{\%}$ \\
\hline Rasional & 35 & 35 \\
Tidak Rasional & 65 & 65 \\
Total & 100 & 100 \\
\hline
\end{tabular}

nilai laju filtrasi glomerulus $>50-59 \mathrm{ml} /$ menit tidak memerlukan penyesuaian dosis ketorolak. Berdasarkan penelitian Haryati (2019) bahwa terdapat $44,97 \%$ obat pada pasien geriatri rawat inap yang tidak rasional, dan ketorolak merupakan salah obat yang sering kali diberikan pada pasien geriatri dan memerlukan penyesuaian dosis yang didasarkan pada nilai laju filtrasi glomerulus pasien (Haryati 2019). Persentase rasionalitas pendosisan ketorolak pada pasien geriatri dengan penurunan fungsi ginjal dapat dilihat pada tabel III.

Pada penelitian ini dosis intravena ketorolak yang diberikan ialah $30 \mathrm{mg}$ dengan interval/frekuensi pemberian yang bervariasi. Rata-rata durasi pemberian obat ketorolak selama 3 hari. Dosis yang direkomendasikan berdasarakan pustaka Drug Information Handbook untuk pasien dengan $\mathrm{CrCl}$ 10-50 $\mathrm{mL} /$ menit adalah 7,5 -15 $\mathrm{mg}$ IM atau IV setiap 6 jam dan durasi tidak melebihi 5 hari. Dosis penyesuaian berdasarkan perhitungan manual menggunakan formula Giusti Hayton adalah 7,5$20 \mathrm{mg} / 6$ jam. Namun pada penelitian ini ditemukan ketidakrasionalan dosis dan durasi dimana dosis yang diberikan yaitu $30 \mathrm{mg} / 8 \mathrm{jam}$ dan beberapa pasien diterapi melebihi 5 hari.

\section{Hubungan Rasioniltas dengan efektivitas terapi}

Kategori pendosisan ketorolak yang rasional dengan efektivitas tercapai sebesar $85.7 \%$ atau sebanyak 30 pasien, sedangkan untuk efektivitas tidak tercapai adalah $14.3 \%$ atau sebanyak 5 pasien. Persentase kategori pendosisan ketorolak yang tidak rasional dengan efektivitas tercapai adalah $83.1 \%$ atau sebanyak 54 pasien, sedangkan untuk efektivitas tidak tercapai adalah $16.9 \%$ atau sebanyak 11 pasien. Data terkait hubungan rasionalitas pendosisan ketorolak dengan efektivitas terapi dapat dilihat di tabel IV. Analisis hubungan hubungan rasionalitas pendosisan ketorolak dengan efektivitas terapi menggunakan uji statistic Chi-square diperoleh nilai $p=0,954$. Sehingga dapat disimpulkan tidak terdapat hubungan yang signifikan antara rasionalitas pendosisan ketorolak dengan efektivitas terapi ketorolak pada pasien geriatri rawat inap. Hasil penelitian ini sejalan dengan penelitian yang dilakukan oleh Haryati (2019) terkait rasionalitas bahwa tidak terdapat hubungan yang signifikan antara rasionalitas dosis dengan efektivitas terapi pada pasien geriatri rawat inap $(p>0,05)$. Hal tersebut disebabkan kategori ketidakrasionalan pada penelitian ini adalah dosis berlebih dimana dosis yang didapatkan adalah $30 \mathrm{mg}$ diberikan secara intravena sehingga efek analgesik dapat tercapai. Berdasarkan penelitian randomized double-blind trial menyebutkan pemberiaan ketorolak dengan dosis $10 \mathrm{mg}$ secara intrvena dapat memberikan efek analgesik yang efektif. Pemberian ketorolak secara intravena dengan dosis 10,15 dan $30 \mathrm{mg}$ memiliki profil analgesik yang sama pada pemberian singkat untuk nyeri sedang sampai berat (Motov dkk., 2017).

\section{Hubungan Rasionalitas Pendosisan dengan Kejadian Efek samping obat}

Berdasarkan penelitian yang telah dilakukan baik kelompok yang rasional dan tidak rasional tidak ditemukan adanya efek samping yang terjadi akibat penggunaan obat. Hubungan rasionalitas pendosisan ketorolak dengan kejadian efek samping dapat dilihat pada tabel IV.

Efek samping pada penggunaan ketorolak terutama pendarahan pada saluran pencernaan tidak terjadi karena penggunaan ketorolak pada pasien geriatri diberikan bersama omeprazole ataupun ranitidin injeksi. Hal ini sesuai dengan penelitian yang dilakukan oleh Haryati (2019) bahwa pada pasien geriatri yang menerima ketorolak bersama dengan ranitidine tidak ditemukan efek samping pada gastrointestinal. Omeprazole merupakan obat golongan penghambat pompa proton yang 
Syaifullah Saputro, et al

Tabel IV2. Hubungan Rasionalitas Pendosisan Ketorolak dengan Efektivitas Terapi pada pasien Geriatri dengan Penurunan Fungsi Ginjal di Rawat Inap RSUD Benyamin Guluh

Kab. Kolaka

\begin{tabular}{lccc}
\hline \multirow{2}{*}{ Rasionalitas } & \multicolumn{2}{c}{ Efektivitas Terapi } & \multirow{2}{*}{$p$} \\
\cline { 2 - 3 } & Tercapai n (\%) & Tidak Tercapai n (\%) & \multirow{2}{*}{0,954} \\
\hline Rasional & $30(85,7 \%)$ & $5(14,3 \%)$ & $11(16,9)$ \\
Tidak Rasional & $54(83,1)$ & $11)$ & \\
\hline
\end{tabular}

Tabel V3. Hasil Analisis Multivariat Variabel Perancu

\begin{tabular}{ccccc}
\hline & Variabel & Tidak Tercapai & Tercapai & p-value \\
\hline \multirow{3}{*}{ Usia (tahun) } & $60-69$ tahun & 52 & 9 & \\
& $70-79$ tahun & 23 & 7 & 0,762 \\
& $>80$ tahun & 9 & 0 & \\
\hline
\end{tabular}

*Uji Multivariat, tingkat probabilitas 95\% $(\alpha<0,05)$

dapat mengurangi sekresi asam pada lambung. PPI efektif dalam mengurangi kejadian ulkus peptikum dan kerusakan pada mukosa yang diakibatkan oleh penggunaan NSAID (Gwee dkk., 2018). Sedangkan efek samping gagal ginjal akut kemungkinan terkait durasi pemberian ketorolak. Hasil penelitian menunjukkan bahwa ketika digunakan selama 5 hari atau lebih singkat (berdasarkan rekomendasi label obat), ketorolak tidak meningkatkan resiko terjadinya gagal ginjal akut (Feldman, 1997).

\section{Hubungan variabel pengganggu dengan efektivitas terapi}

Berdasarkan tabel $\mathrm{V}$ yang menunjukan data hasil analisis multrivariat variabel pengganggu, didapatkan bahwa nilai $p$ atau signifikansi dari varabel usia $p>0,05$ sehingga dapat disimpulkan bahwa outcome pengobatan ketorolak pada pasien geriatri dengan penurunan fungsi ginjal tidak dipengaruhi oleh usia. Walaupun usia merupakan salah satu variabel yang dapat mempengaruhi persepsi seseorang terhadap nyeri dimana terdapat hubungan yang linear antara usia dan nyeri, dimana frekuensi, keparahan, serta nyeri persisten meningkat seiring dengan bertambahnya usia (Eltumi dan Tashani, 2017). Namun pada penelitian ini ditemukan bahwa usia tidak mempengaruhi ketercapaian outcome pada pengobatan nyeri. Hal ini sejalan dengan penilitian Dirga pada tahun 2019 menyebutkan bahwa usia bukan merupakan faktor yang dapat mempengaruhi outcome pengobatan nyeri (Dirga dkk., 2019).

\section{KESIMPULAN}

Hasil penelitian menunjukkan dari 100 sampel pasien geriatri rawat inap yang mendapatkan ketorolak pada penelitian ini terdapat sebanyak 35 sampel pasien (35\%) yang mendapatkan ketorolak dengan pendosisan yang rasional dan 65 sampel pasien (65\%) mendapatkan pendosisan yang tidak rasional. Pendosisan rasional dengan efektivitas tercapai sebesar $85.7 \%$ dan tidak tercapai $14.3 \%$, pendosisan tidak rasional dengan efektivitas tercapai sebesar $83.1 \%$ dan tidak tercapai sebesar $16.9 \%$. Namun tidak terdapat hubungan yang signifikan antara rasionalitas dosis dengan efektivitas $(p>0,05)$ maupun kejadian efek samping.

\section{DAFTAR PUSTAKA}

Abdulla, A., Wright, P.N., Ross, L.E., Gallagher, H., Iyasere, O., Ma, N., dkk., 2017. Proceedings from the Symposium on Kidney Disease in Older People: Royal Society of Medicine, London, January 19, 2017. Gerontology and Geriatric Medicine, 3: 233372141773685 .

Andini, F.,2015. Risk factors of low back pain in workers. 4(1), pp. 13-15

Chan, 2014. Ketorolac Prescribing Practices in an Acute Care Hospital and the Incidence of Acute Renal Failure. World Journal of Nephrology and Urology.

Christensson, A. dan Elmståhl, S., 2011. Estimation of the Age-Dependent Decline of Glomerular Filtration Rate from Formulas Based on Creatinine and Cystatin C in the General Elderly 
Population. Nephron Clinical Practice, 117: c40-c50.

Dirga, D., Nugroho, A.E., dan Pramantara, D.P., 2019. Faktor-Faktor yang Memengaruhi Clinical Outcome Nyeri pada Pasien Diabetes Neuropati di Poliklinik Penyakit Dalam RSUD Kota Yogyakarta. Jurnal Kefarmasian Indonesia, 106-113.

Durakovi, Z. dan Vitezi, D., 2013. Pharmacodynamics and pharmacokinetics in the elderly. Period biol, 115: 4.

Eltumi, H.G. dan Tashani, O.A., 2017. Effect of Age, Sex and Gender on Pain Sensitivity: A Narrative Review 12.

Feldman, H.I., 1997. Parenteral Ketorolac: The Risk for Acute Renal Failure. Annals of Internal Medicine, 126: 193.

Gwee, K.-A., Goh, V., Lima, G., dan Setia, S., 2018. Coprescribing proton-pump inhibitors with nonsteroidal anti-inflammatory drugs: risks versus benefits. Journal of Pain Research, Volume 11: 361-374.

Hassan, Y., Al-Ramahi, R., Aziz, N.A., dan Ghazali, R., 2009. Drug Use and Dosing in Chronic Kidney Disease 38: 9.

Kappel, J. dan Calissi, P., n.d. Nephrology: 3. Safe drug prescribing for patients with renal insufficiency 5.

Leong, I.Y., Farrell, M.J., Helme, R.D., dan Gibson, S.J., 2007. The Relationship Between Medical Comorbidity and Self-Rated Pain, Mood Disturbance, and Function in Older People with Chronic Pain 6.

Modig, S. dan Elmståhl, S., 2018. Kidney function and use of nonsteroidal antiinflammatory drugs among elderly people: a cross-sectional study on potential hazards for an at risk population. International Journal of Clinical Pharmacy, 40: 870-877.

Motov, S., Yasavolian, M., Likourezos, A., Pushkar, I., Hossain, R., Drapkin, J., dkk., 2017. Comparison of Intravenous Ketorolac at Three Single-Dose Regimens for Treating Acute Pain in the Emergency Department: A Randomized Controlled Trial. Annals of Emergency Medicine, 70: 177-184.

Racine, M., Tousignant-Laflamme, Y., Kloda, L.A., Dion, D., Dupuis, G., dan Choinière, M., 2012. A systematic literature review of 10 years of research on sex/gender and pain perception - Part 2: Do biopsychosocial factors alter pain sensitivity differently in women and men?: Pain, 153: 619-635. 